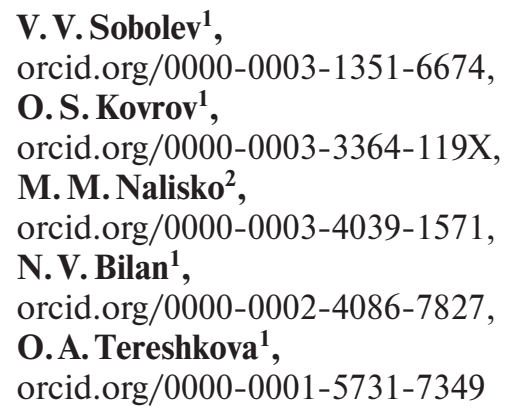

1 - Dnipro University of Technology, Dnipro, Ukraine, e-mail: velo1947@ukr.net

2 - State Higher Education Establishment "Pridneprovsk State Academy of Civil Engineering and Architecture", Dnipro, Ukraine

\title{
COMPOUND PHYSICAL AND MECHANICAL EFFECTS STIMULATING METASTABLE DIAMOND FORMATION
}

Purpose. To synthesize diamond polycrystals in a thermodynamically stable region, and to grow up a single crystal shell under conditions of thermodynamic metastability. To investigate some physical properties and features of the internal structure for synthesized single crystals for the development of new models and hypotheses regarding the issue of diamond genesis.

Methodology. Experimental studies using shock-wave effects on a metal alloy containing non-diamond carbon. Methods of infrared and ultraviolet spectroscopy, X-ray phase analysis, electron paramagnetic resonance, isotope analysis, differential thermal analysis, electron microscopy, and others are used. The synthesis of nanocrystalline diamond particles as nuclei for growing single crystals is carried out by the shock-wave method using profiled shock waves.

Findings. A complex of physicochemical methods for studying the grown diamond monocrystals has been carried out. The reasons for the discrete growth of diamond and the retention of the central inclusion (a polycrystalline diamond of shock-wave origin) in the process of growth have been established and analyzed. It is shown that the discreteness of diamond formation is characteristic only for thermodynamically metastable conditions. The results of the experiments give grounds to make an assumption about the metastable growth, including of diamonds from primary deposits.

Originality. The hypothesis has been developed concerning the origin of diamond nanoparticles in interstellar carbon clouds which refer exclusively to central polycrystalline inclusions in a monocrystal diamond shell. The hypothesis eliminates the scientific contradiction that arises in all cases when attempts are made to interpret the natural discreteness of diamond formation based on the regularities of the "graphite-diamond" state diagram. Possible causes of discrete diamond formation in nature and the scenario of the formation of diamond nanocrystals in an interstellar cloud of atomic carbon have been considered.

Practical value. The value of the experimental research results refers to the development of a non-energy-intensive technology for the growing large diamond monocrystals at temperatures of 500-1400 K, and pressures of 105-107 Pa.

Keywords: diamond, metastability, discreteness, diamond formation, nanocrystals, monocrystal nucleus, protoplanetary cloud

Introduction. Diamond is the only mineral on the Earth that has a unique complex of extreme physical and chemical properties and still has an ambiguous history of its origin. It is no secret that diamond on the Earth is a widespread mineral, whose size ranges from several nanometers to several centimeters. In addition, there are no special physical laws for a diamond in accordance with which the processes of its formation in nature would be carried out. The fundamental importance in the implementation of such processes belongs to the state of the initial carbon, the phase state of the medium (solid, liquid, gas), in which diamond formation occurs, thermodynamic parameters and the state of the chemical activity of the system. The physical and technical characteristics of the synthesized crystals, including the features of the internal structure, depend on the selection of the starting material and the method of energetic action on the physical-chemical system. The results of a comparative analysis of the features of the internal structure of natural and synthetic single crystals could be of great interest, taking into account the parameters of their formation, the presence of a genetic center in single crystals. The mineralogical specialization and the difference in the chemical composition of inclusions in one diamond, depending on the approach to the crystal surface, are also of great interest. How contradictory can be the interpretation of the scenario of formation, for example, of syngenetic inclusions in natural diamonds and the relationship of thermodynamic parameters to the chemical activity of the surface of a growing crystal?

(c) Sobolev V.V., Kovrov O. S., Nalisko M. M., Bilan N. V., Tereshkova O.A., 2021
Literature review. The results of the analysis of the ratio of carbon isotopes and helium isotopes in natural diamonds [1, $2]$ in comparison with any samples of diamond synthesized in the stable region are extremely important. The issues of discrete growth, which is characteristic of primary and alluvial diamond crystals, are relatively rarely discussed in the publications [3].

Since the middle of the $20^{\text {th }}$ century, a significant number of facts appeared periodically that could not be explained in terms of the theory of stable diamond formation (hypothesis of mantle origin). The contradiction was eliminated by the assumption of metastable crystallization of diamond in nature [4-7]. The main theory of the origin of diamonds contradicts the finds of single crystals in metamorphic rocks [8-10], volcanic rocks of various compositions [11, 12], in deep and hypabyssal hyperbasites [13, 14], in ultrabasic rocks [15], basic and alkaline-basaltoid composition, numerous finds of non-kimberlite diamonds, cited by V.N. Lodochnikov in his monograph (1936). Analyzing the presence of diamonds in connection with hyperbasites, the author of the article [16] assumes that the formation of diamonds could occur at temperatures up to $1300{ }^{\circ} \mathrm{C}$ and pressures in the range $(2-6) \cdot 108 \mathrm{~Pa}$, i. e. in the field of thermodynamic metastability. Small diamonds first discovered in Neogene sandy deposits [17], and lonsdaleite crystals found in placers [18], do not yet have a scientifically substantiated mechanism of formation. Diamonds in the graphite shales of Liberia [19], the well-known deposits of Kumdykul (North Kazakhstan) [20] and Haggerty (West Africa) are crustal formations of diamond in association with graphite within deep fault zones, which may indicate in favor of metastable growth. During magmatic, metasomatic, meta- 
morphic and hydrothermal processes, the formation of minerals is actively involved in the fluid phase, which contains mainly such volatile components as hydrogen, oxygen and carbon. As a result of studies on changes in the equilibrium state of fluid-mineral systems depending on changes in the parameters $P-T-f \mathrm{O}_{2}$, it was established [21] that fluids play an important role in the formation of minerals and deposits of diamond, graphite, etc. According to the author [21], the found parameters $P=(3-220) \cdot 105 \mathrm{~Pa}, T=688-1083 \mathrm{~K}, f \mathrm{O}_{2}=-(18.08-$ - 23.26) $\cdot 10^{5} \mathrm{~Pa}$ are the most favorable for metastable diamond formation, i.e. e. exclusively for crustal diamond formation. The main theory of the mantle origin of all diamonds without exception is based on the concept of stable conditions corresponding to the region of high temperatures and pressures [22-24]. Such ideas about the deep genesis of diamond were formed on the idea of P. A. Wagner (1909); the concept of high pressures and temperatures was confirmed by thermodynamic calculations by O. I. Leipunsky (1939).

The first reproducible synthesis of diamond was carried out in 1953 in Sweden. The synthesis was carried out in an apparatus for obtaining high pressure (more than $40 \cdot 108 \mathrm{~Pa}$ ) and high temperature (more than $1700 \mathrm{~K}$ ), described in [25]. Studies on various catalyst metals, the choice of the initial carbon raw material [26] and the improvement of the design of high-pressure chambers [27], the study on the properties of synthesized crystals, the fields of application of diamond as an engineering material are still considered as priority scientific directions. Obviously, the theoretical basis for the synthesis of diamond at high pressures and high temperatures is the well-known diagram of O.I. Leipunsky, which determines the stability fields of graphite and diamond, the nature of the transition of graphite to the superhard carbon phase.

The fact of scientific and technical success in the growth of diamond single crystals indicates mainly that high temperatures and high pressures are necessary for the dissolution of graphite in the metal melt and the delivery of atomic carbon to the diamond surface. However, the explanation of the formation of diamond in nature with reference to the scenario of continuous growth in high-pressure apparatuses leads to a fundamentally different mechanism of diamond formation, which has no analogues in nature. As for the conditions of stable diamond formation in the earth's crust, their most probable realization can be caused by an explosion, cavitation, and so on [21].

Since 1961, reports on the shock-wave compression of graphite and the synthesis of diamond polycrystals [28-30] and lonsdaleite $[31,32]$, the methods of physicochemical and analytical studies of the obtained polycrystals [33-35] have been appearing regularly in scientific publications. Physical models and mechanisms of diamond formation were investigated [36-38], an active search for high-performance methods of dynamic synthesis was carried out [39, 40], promising areas of application with additional plastic deformation of cast iron to explosive action [41] and thermal cyclic processing of cast iron after shock compression [42] were studied. In connection with the discovery of a deposit of impact diamondolonsdaleite minerals in the rocks of the Popigai crater [43], a comparative analysis of the physicochemical properties of these diamonds and graphite synthesized by shock compression showed the absence of fundamental differences in the formation mechanisms. In the case when graphite serves as the initial substance, the impact mechanism of the formation of diamond polycrystals can be considered as a mechanism inherent in diamond formation in nature. However, the starting material can be not only graphite and not only a strong impact can stimulate the synthesis of diamond, for example, cavitation of gas bubbles in moving magma [44]. Investigation of the geochemical characteristics of micro-diamond particles found in the products of the eruption of the Tolbachik volcano in Kamchatka, and analysis of the totality of the data obtained, allowed the authors of [45] to conclude that diamonds were formed during fluid cavitation. On the whole, the significance and role of shock (explosive) events in the history of the formation of polycrystalline diamond and its polymorphic modifications were decisive.

The fundamental possibility and high probability of the formation of metastable diamond in nature is illustrated by the results of long-term studies on the mechanisms of diamond nucleation [46-48], the growth of diamond films from gas $[49,50]$ and their physicochemical properties [51, 52]. Experimental and theoretical results of studies on the growth of the diamond phase from the gas formed the basis of the technology for the production of diamond single crystals from the gas phase (CVD method) [50]. In the production of diamond films from gas, pressures below $10^{5} \mathrm{~Pa}$ are applied. This suggests that, in nature, the synthesis of diamond from gas can be carried out in a wide range of pressures: from less than $10^{5} \mathrm{~Pa}$ (CVD method) to $1010 \mathrm{~Pa}$ more during cavitation and the maximum temperature can be several thousand Kelvins.

Impact phenomena caused by collisions of large meteorites with the Earth are one of the most significant events in the early evolution of the Earth, primarily of the Earth's crust and the development of life [53, 54]. Impact events stimulated subsequent events on Earth such as extensive volcanism, increased endogenous geological and local seismic activity. An extremely effective influence of the simultaneous or sequential action of several physical factors has on the physicochemical transformations in materials. For example, mechanicchemical activation of siderite (also jasper and other carbonates) upon further heating and exposure to a weak electric field leads to the formation of conductive phases [55]. In coal of the middle stage of coalification at temperatures not exceeding $328 \mathrm{~K}$ and pressures up to $5 \cdot 10^{6} \mathrm{~Pa}$, under the influence of a weak electric field, destructurization occurs with the formation of molecules of methane and other gases [56]; microstructures in the direction of increasing the degree of coalification [57]. It is possible to assume the manifestation of a mechanism of similar physicochemical transformations in mineral and ore-forming processes occurring in the conditions of the earth's crust [58]. The results of processing carbon-containing metal alloys using additional physical influences to impart an excess energy state to the microstructure of the alloy often give unexpected results.

Exposure to a shock wave occurs with simultaneous heating of carbon-containing alloys [59], additional thermal-mechanical [60] and thermal cycling treatment of alloys [61] either before or after shock-wave treatment. In addition to the above methods, electromagnetic treatment of a solid carboncontaining medium after synthesis in high-pressure chambers was used [63, 64]. As a result of using each type of complex treatment, for the first time, single crystals of diamond were synthesized in the size range from 30 to $960 \mu \mathrm{m}$. It is likely that in the region of thermodynamic stability, because of the transition of graphite to diamond, on the formed polycrystals as on substrates, a single crystal shell grew in the region of metastability.

Geological study on primary diamond deposits in Yakutia [65] and South Africa [66], the problem of the discreteness of natural diamond formation [67], crystal morphology [68], inclusions and internal structure [69], physicochemical properties, regularities of optical and electronic processes in natural and synthetic crystals [70, 71], genetically informative impurities [72], the study on impact diamond polycrystals [43] and the isotopic composition of helium in diamond from meteorites $[1,2]$, indicate the ambiguity of existing opinions regarding the mechanisms of natural diamond formation.

Comparisons of the controlled parameters of metastable diamond synthesis with the most probable parameters of the physical-chemical conditions of the geological envi- 
ronment are necessary to solve the problem of the genesis of diamond deposits and the mechanisms of diamond formation, which are relevant, still being the subject of heated discussions.

The purpose of the work is to synthesize diamond polycrystals in a thermodynamically stable region, and to grow a single crystal shell under conditions of thermodynamic metastability. To investigate some physical properties and features of the internal structure of synthesized single crystals for the development of new models and hypotheses in the problem of diamond genesis.

Materials and research methods. Fig. 1 presents a diagram of a device for synthesizing diamond using a profiled shock wave. The device works as follows. Laser pulsed radiation 1 with a wavelength of $1.06 \mu \mathrm{m}$ is directed to the surface of the photosensitive explosive composite 2 . In this case, the surface of the composite is completely covered by the scattered laser beam.

A feature of this detonation excitation scheme is the formation of a flat detonation front in the composite layer and, accordingly, in the explosive charge 3 . When a flat detonation front collides with a metal plate 4 , due to the action of the pressure of the explosion products simultaneously on its entire surface, the shape of the plate is practically not distorted. The plate, flying a certain distance (gap) $h$, strikes the surface of the iron-carbon alloy 5 , generating an impact pressure in the alloy of more than $65 \mathrm{GPa}$, and in the inclusions of graphite - at least $30 \mathrm{GPa}$. To prevent the destruction of the alloy after being hit by a plate, a massive metal container was used 6 . The chemical composition of the alloy: $\mathrm{C}-3.9 \%$, the content of $\mathrm{Mn}, \mathrm{Si}, \mathrm{P}, \mathrm{S}-$ only $3.1 \%$, Fe - the rest. When preparing and carrying out the experiments, an initiating photosensitive explosive composite of the VS brand was used [73], the explosive charge was made of a cast TNT/RDX alloy (36/64), detonation velocity $\sim 7960 \mathrm{~m} / \mathrm{s}$, density $\sim 170 \mathrm{~kg} / \mathrm{m}^{3}$. The size of the gap $h$ (Fig. 1) is functionally related to the thickness and specific gravity of the plate material; depends on the ratio of the masses of the explosive charge and the plate. The parameters of the shock-wave treatment can be estimated according to [74]. The studies were based on the use of differential thermal analysis, isotope analysis, electron paramagnetic resonance, a complex of mineralogical studies, X-ray analysis, and others.

Research results and their discussion. Experimental proof of the discrete process of diamond formation under controlled thermodynamic conditions is extremely important for the creation of a theoretical model of diamond genesis [66, 75]. Obvious physical contradictions arise when analyzing the experimental data and comparing those obtained ones in the study on the internal structure of synthetic single crystals with

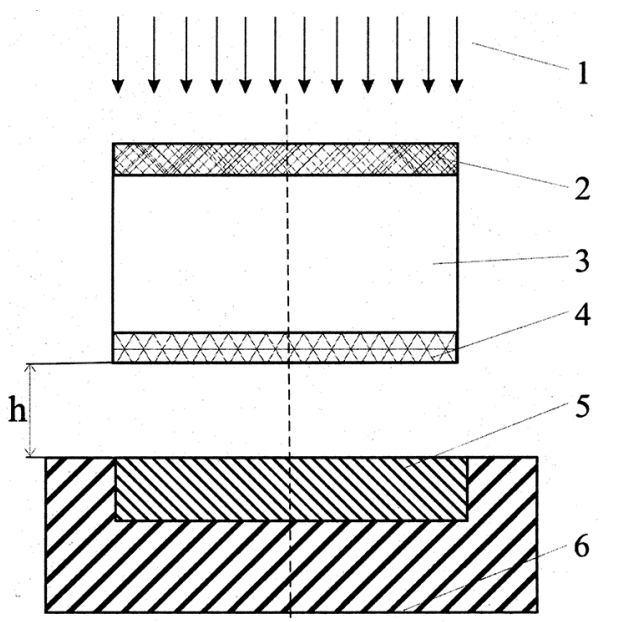

Fig. 1. The diagram of a device for shock-wave diamond synthesis natural diamond samples, taking into account calculations of the thermobaric parameters corresponding to the conditions of nucleation and growth. According to the Leipunsky diagram, diamond can grow if the original carbon material is graphite. It is necessary to ensure the following conditions for obtaining diamond monocrystals: constant thermodynamic parameters and their correspondence to diamond stability field, graphite dissolving and formation of atomic carbon in catalyst metal, continuous process of diamond formation, constant value of the degree of supersaturation of the system with carbon. The necessity of the parameters is self-evident, the "continuity" of the process should be commented upon. The need to comply with the listed conditions for the synthesis is obvious, and then we comment on the concept of process continuity. In the synthesis processes of diamond single crystals, atomic carbon is obtained from graphite dissolved in liquid metal in the field of diamond within the range of high temperature and pressure. The peculiarity of diamond growth in the field of its thermodynamic stability consists in the fact that in the case of changing the degree of metal-carbon system oversaturation and overcooling, the continuation of the diamond particle growth is impossible. If the temperature and pressure in the system change, there appear new nuclei in accordance with the changed thermodynamic conditions. It is known that growing diamond in high-pressure chambers requires precise keeping to the set values of pressure and temperature.

As experiments show, diamond monocrystals can grow in solid, liquid and gaseous media on diamond seeds in the zone of thermodynamic metastability. In our experiments, first stage of the synthesis was conducted in the solid iron-carbon alloy on polycrystal nuclei, which were in fact diamonds obtained by the preliminary shock-wave treatment of the alloy. During the second stage, monocrystals grow within the range of temperatures $800-1100 \mathrm{~K}$ and pressures $10^{5}-10^{7} \mathrm{~Pa}$. The shock-wave synthesis is characterized by the microsecond long duration with the finished product in the form of polycrystal aggregates (interconnected nanoscale single crystals) of the size $3 / 0 \mu \mathrm{m}$.

The process of monocrystal shell growth on polycrystal nuclei lasted from several tens of minutes to several hours. We studied diamond crystals sized from $4 \cdot 10^{-5}$ to $10^{-4} \mathrm{~m}$, Fig. 2.

Because of plastic deformation and subsequent shockwave treatment of the metal alloy, diamond single crystals of different color, habit and size were deposited. Especially many crystals of irregular shape were deposited. The formed diamond powder contains a lot of yellow-greenish crystals (about $30 \%$ ) and colorless crystals (about $45 \%$ ), light green ( $15.5 \%$ dark green, up to black crystals). Pale pink and pink crystals are found rarely, do not have a clear faceting and from the total mass of diamond powder they are not more than $1 \%$. The average crystal size is about 50 microns. A crystal with a clear octahedral facet, 75 microns in size was found. Twins and intergrowths mainly represent dark green and black ones and their size is not more than 1200 microns. There are single intergrowth crystals about 1000 microns in size. Among the crystals of light green color, there are single crystals with a perfect facet, represented by octahedra and, less often, cuboctahedrons. The sizes of crystals do not exceed 350 microns; in some of them dark inclusions are observed. Crystals has a skeletal structure of faces, which is the result of the high growth rate characteristic of kinetic regime. In addition to diamond, large quartz single crystals with sizes of about $0.5-1.5 \mathrm{~mm}$ have been identified.

The grown monocrystals are fundamentally different from those synthesized in high-pressure chambers. Most physical properties and their inner structure are analogous or practically identical to those of the diamonds from primary deposits (in particular, the presence of a genetic center). Here are the main characteristics of the synthesized metastable diamond crystals. 


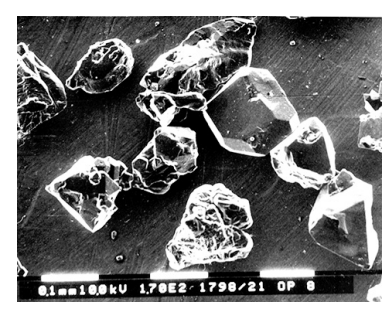

$a$

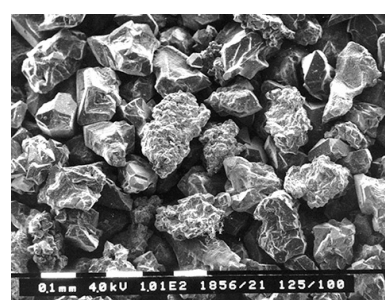

$b$

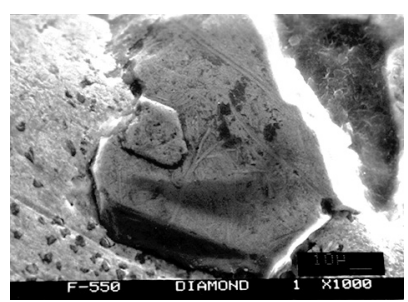

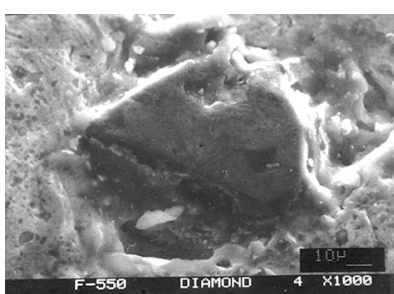

$d$

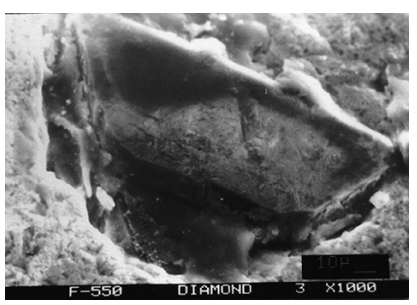

Fig. 2. Diamond monocrystal grown in the solid medium at pressure up to $1 \mathrm{MPa}$ and temperature up to $1100 \mathrm{~K}$ :

$a$ - thermal cycling treatment after shock wave one; $b$ - thermomechanical treatment before the impact of a shock wave; $c, d-m e c h a n i c a l$ treatment of the alloy after treatment with a shock wave; $e$ - treatment of the heated alloy by a shock wave

1. Structurally, the experimentally grown diamond monocrystals (Fig. 2) are characterized by the presence of two zones: monocrystal shell with dislocations density (1.8$6.3) \cdot 10^{12} \mathrm{~m}^{-2}$ and polycrystal center with dislocations density $10^{17}-10^{18} \mathrm{~m}^{-2}$. In our experiments, the polycrystal center is a diamond synthesized in iron-carbon alloy under the shockwave impact. An example of a Lauegram (Fig. 3) that shows a continuous diffuse ring on the background of individual clear and sharp diffraction maximums. Asterism is a consequence of the effect produced by polycrystal nucleus, which enhances inner deformations of the monocrystal. Hence, the studied crystals have a genetic center with rudiments of the nucleus of dynamic origin.

A diamond synthesized in a stable region has no genetic center. In the case of deviation from equilibrium within the stability field, diamond growth stops, and a new crystal nucleates. The formation of a new phase nucleus is directly related to fluctuations in the system and is described using Gibbs thermodynamic potentials. V.V. Varshavsky when studying central inclusions as possible seeds for diamond growth raised the issue of central nucleus for the first time in 1968.

The work [2] discusses research into the ratio of isotopes ${ }^{3} \mathrm{He} /{ }^{4} \mathrm{He}$ in diamonds from South African mines and concludes that this value is placed within the range $(3.2 \pm 0.25) \cdot 10^{-4}$, i.e. it is two times as high as the planetary value $(1.42 \pm 0.25) \cdot 10^{-4}$. This assessment corresponds to the ratio of sun-type He isotopes. Such unusually high ratio can refer to the protogenic helium that may probably exist in the protoplanetary cloud. Estimation of this helium isotopes ratio can be interpreted as diamond nanocrystals' formation from atomic carbon in interstellar gas. In view of this argument, the authors [39] supposed the reasons for the separation of the processes, being

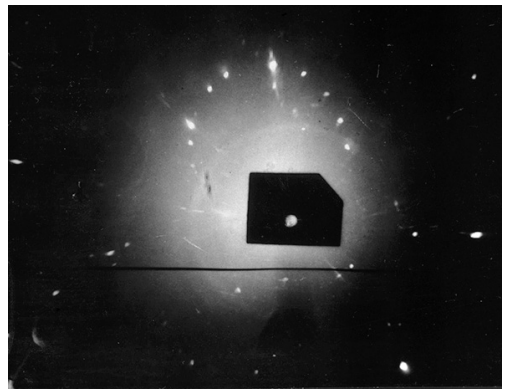

Fig. 3. Lauegram of a metastable diamond monocrystal synthesized in the solid alloy [61] fundamentally different in thermodynamic parameters. It is logical that the central nucleus is preserved, as well as its specific crystal structure and properties different from the monocrystal shell.

2. We analyzed the graphite isotopes ratio ${ }^{13} \mathrm{C} /{ }^{12} \mathrm{C}$ in the initial alloy, in graphite and diamond after the shock-wave impact and in the grown diamond monocrystal. Table 1 shows that the values of $\Delta^{13} \mathrm{C}$ in the initial graphite, graphite and diamond after the shock wave impact were respectively -23 , $-23.4,-24.3 \%$. For the grown diamond, this value $\Delta^{13} \mathrm{C}$ is $31 \% 0$.

The central part of the grown crystal contains the same amount of $\Delta^{13} \mathrm{C}$ as polycrystalline explosive diamonds, i.e. $-24.4 \%$. Thus, the value of $\Delta^{13} \mathrm{C}$ in explosive polycrystalline diamond and in the central part of the grown crystal is basically the same. The anomalous difference between the $\Delta^{13} \mathrm{C}$ values in the polycrystal synthesized in the shock wave and in the grown single crystal indicates that, in the first case, the diamond was formed directly from graphite. In the second case, the single crystal grew due to atomic carbon coming from the solid solution to the growing diamond, while the single crystal shell has a value of $-31 \%$. In the classification of diamonds by isotopic composition [76], the synthesized single crystals can be conditionally assigned to the group of delta natural diamonds formed at low pressure from isotopically light carbon. With a wide range of isotopic fractionation under metastability conditions, diamond grows even at low carbon supersaturations.

3. Electron paramagnetic resonance of diamonds showed that the samples of the synthesized crystals form a separate group. The physical characteristics of these diamonds differ from those of industrial synthesized diamonds with HPHT.

Table 1

Isotope composition of carbon in the phases of metal alloy and diamond zones

\begin{tabular}{|l|c|}
\hline \multicolumn{1}{|c|}{ Object of analysis } & $\Delta^{13} \mathrm{C}, \% \circ$ \\
\hline Graphite inclusions in the metal alloy: & \\
- before shock wave impact & -23.0 \\
- after shock wave impact & -23.4 \\
\hline Diamond polycrystals, synthesized in the shock wave & -24.3 \\
\hline Grown diamond monocrystals: & \\
- central nucleus (center) & -24.4 \\
- monocrystal shell & -31.0 \\
\hline
\end{tabular}


EPR study on diamond crystals

\begin{tabular}{|c|c|c|}
\hline $\begin{array}{l}\text { Type of studied diamonds, methods of } \\
\text { their production }\end{array}$ & 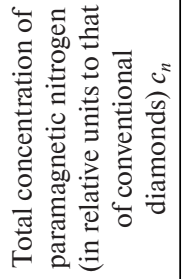 & 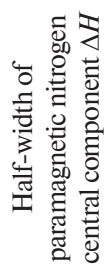 \\
\hline Conventional HPC-synthesized crystals & 1.0 & 1.0 \\
\hline $\begin{array}{l}\text { Diamonds grown in metal alloy: } \\
\text { sample } 1 \\
\text { sample } 2 \\
\text { sample } 3\end{array}$ & $\begin{array}{l}1.22 \\
1.41 \\
1.38\end{array}$ & $\begin{array}{l}1.37 \\
1.02 \\
0.92\end{array}$ \\
\hline
\end{tabular}

Crystals of solid-phase synthesis diamond have a high concentration of nitrogen, which, on average, is more than $30 \%$ higher than that of industrial crystals. In this case, the halfwidth of the central component of paramagnetic nitrogen in relative units to industrial diamonds $(H=1)$ is $\Delta H=0.94$, Table 2.

4. When exposed to ultra-violet radiation at the room temperature, diamond crystals luminesce, emitting blue light $(\approx 60 \%)$, yellow-green light $(\approx 35 \%)$ and orange light $(\approx 5 \%)$. The crystals under study are represented by octahedra, less often by cuboctahedra and rhombic dodecahedrons. Such properties are characteristic of natural diamond crystals, but not for grown under HPHT in the region of stability.

5. The thermal-oxidative resistance of diamond crystals with a size in the range of 80-100 microns was investigated, after heating to $950 \mathrm{~K}$, using the method of mathematical description of physical adsorption, the specific surface area was measured, which was about $1 \mathrm{~m}^{2} / \mathrm{g}$. Exotherms of oxidation were studied at different heating rates (degree/min): 10; 5; $2.5 ; 1.25$. The type of exotherms indicates a wide grain size composition of the crystals of the studied diamond and the predominant presence of large particles, since the low-temperature branch is much stretched and a sharp decline is observed after reaching the maximum rate of the oxidation reaction $T_{m}$. After reaching the maximum $T_{m}$, about $30 \%$ of the diamond is additionally oxidized. Irregularities on the shoulders of exotherms are most pronounced at low heating rates, which is most likely associated with a high imperfection of the crystal structure and the presence of impurities in diamonds.

Fig. 4 shows a graph plotted in the coordinates $\ln K / T_{m}^{2}-1 / T_{m}$ for calculating the kinetic constants of the oxidation process. The activation energy $E_{a}$ was determined from the tangent of the slope of a straight line, and the exponential factor $A$ was calculated using the $\mathrm{O}$. Breusov equation

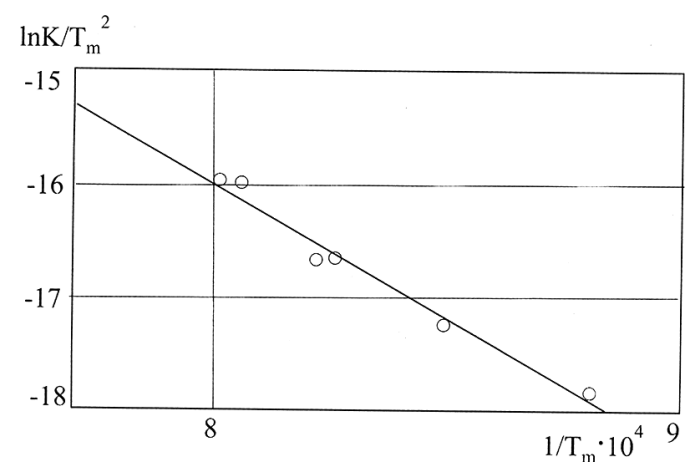

Fig. 4. Dependence of the temperature value of the maximum exotherm (oxidation temperature $T_{m}$ ) on the heating rate of diamond crystals

$$
A=k E_{a}\left[R s_{0} T_{m}^{2}\right] \exp \left(-E_{a} / R T_{m}\right),
$$

where $R$ is a gas constant; $s_{0}$ is a specific surface, $\mathrm{m}^{2} / \mathrm{g}$.

Using the technique [76], the parameters $E_{a}=47.8 \pm$ $\pm 4.8 \mathrm{~kJ} / \mathrm{mol}$ were determined; $A=40 \mathrm{~g} / \mathrm{cm}^{2} \cdot \mathrm{s} ; \ln A=1.7 \pm 0.9$. The temperature $T_{A}$ at which the oxidation state for $t=1000 \mathrm{~s}$ was $1 \%$ was determined from the modified Arrhenius equation [77]

$$
\ln \left(m / m_{0}\right)=A s_{0} t \cdot \exp \left(-E_{a} / R T_{A}\right) .
$$

The $T_{A}$ value required to determine the series of thermaloxidative resistance was found from the equation proposed in [78]

$$
T_{0}=E /\left[R \ln \left(F E_{a} / R k\right]\right),
$$

where $T_{A}$ and $T_{0}$ are respectively 967 and $956 \mathrm{~K}$, whose values are calculated under the condition that $m / m_{0}=0.99$.

The relationship between $T_{m}$ and $T_{0}$ of diamond micropowders is shown in Fig. 5. The values of thermal oxidation resistance of various diamonds show that solid-phase epitaxy diamonds in terms of $\ln A, E_{a}, s_{0}, T_{A}, T_{m}$ and $T_{0}$ values are close to impact diamonds ПИАК-4: $E_{a}=49.1 \pm 1.7 \mathrm{~kJ} / \mathrm{mol}, \ln A=$ $1.7 \pm 0.3, s_{0}=3.1 \mathrm{~m}^{2} / \mathrm{g}, T_{m}=1211 \mathrm{~K}, T_{A}=952 \mathrm{~K}, T_{0}==959 \mathrm{~K}$ [78] and strongly differ from the results obtained in [78] for diamond synthesized into cast iron by shock waves and in high pressure chambers.

The investigated diamonds have a low value of thermal oxidative resistance (TOR). Based on a quantitative comparison of the TOR of diamond powders of different origins, it can be concluded that diamonds obtained under metastable conditions occupy quite a definite place on the straight line describing the relationship between the values of $T_{m}$ and $T_{A}$ (Fig. 5).

The issue of diamond crystal discrete growth can be studied departing from the following assumed scenarios. First, the diamond has a history of deep formation [7, 22-24]. In this situation, we should overcome a basic contradiction related to finding inclusions of eclogitic and ultrabasic paragenesis in a single diamond crystal, central polycrystalline diamond inclusions in diamond monocrystals.

Another issue is related to the carbon source. Using the regularities of the graphite-diamond phase diagram, it is necessary to have an environment in which graphite carbon would dissolve. However, this can happen if the growth medium in the region of high pressures and temperatures corresponding

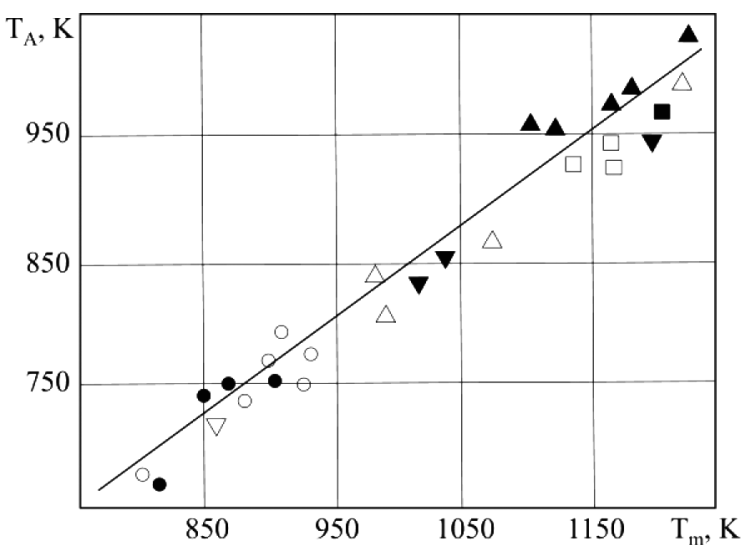

Fig. 5. Dependence of $T_{m}-$ the maximum oxidation reaction rate on $T_{A}$ - temperature corresponding to the oxidation state by $1 \%$ for 1000 s for diamond micropowders:

$\nabla$ - detonation diamonds in explosion products; $\Delta$ - shock-wave synthesis diamonds in a metal-carbon mixture; $\mathbf{\Delta - d i a m o n d s ~ s y n - ~}$ thesized under HPHT; - - diamonds of metastable synthesis in a solid medium; $\square$ - impact diamonds from Popigai deposit; $\bigcirc-$ when detonating explosives with soot; $\bullet-$ when detonating explosives with graphite 
to the stability region of diamond is deficient in electrons in the conduction band, similar to what happens with iron in the austenitic region. Then graphite as a donor will donate electrons with carbon atoms. Thus, doubts arise about the realization of diamond formation in nature according to the scenario of the synthesis of stable diamond in accordance with the theory of O. Leipunsky.

The second scenario - the nucleation of diamond nanocrystals occurs in the earth's crust when extreme pressures and temperatures occur, for example, due to cavitation of gas bubbles during the movement of fluid flows, large-scale shock events with the formation of deposits of impact diamonds, etc. The growth of diamond could continue on the formed polycrystalline substrates under favorable conditions in a solid medium, gas and liquid (hydrothermal diamonds) in the presence of sufficient atomic carbon for the formation of large crystals. With a carbon deficiency, small single crystals are formed. To obtain atomic carbon from the fluid phase, high temperatures and pressures are not required. But carbon can be obtained from the solid phase (graphite) only by dissolution in metals under HPHT conditions.

The third scenario is "exotic", but it does not contradict physical laws. It is assumed that diamond nanocrystals are formed from atomic carbon, concentrated in pure carbon clouds of the interstellar medium, and which, along with interstellar gas and dust, took part in the "construction" of the solar system [39].

Free atomic carbon, forming pure carbon clouds and detected for the first time in interstellar space [79] are subjected to electromagnetic radiation from stars. These atoms can be in different energy states depending on the consumed radiation energy or the gas heat energy. One of carbon atom states is a valent state. Configuration $1 s^{2} 2 s^{2} 2 p^{2}$ can yield two free valences. In this state, the carbon atom possesses energy $0.3 \mathrm{eV}$ and can join one or two one-valent atoms. This is the way in which radicals $\mathrm{CH}$ and $\mathrm{CH}_{2}$ are formed. One-electron transfer $\mathrm{s} \rightarrow p$ doubles the number of valences. Such transfer results in the formation of $s p^{3}$-configuration of valent electrons, which can have any spins and, consequently, form 4 free valences with the energy corresponding to the degree of the basic state excitation $4 \mathrm{eV}$.

If the main, orbital and spin numbers of all the three electrons are the same, there should be some difference at least in their magnetic quantum numbers $m_{i}$. Different magnetic quantum numbers relate to different spacial disposition of electron probability clouds. If the latter are separated in space, the electrons are situated on average further from each other than in the case of the clouds merging. Consequently, the potential energy of repulsion will be lower because it is inversely proportional to the distance between electrons. Hence, when all the three spins of the $2 p$-electrons are parallel, their energy is lower than the energy of three-electron system, when two of them have anti-parallel spins. It can be assumed that in the medium of atomic carbon gas, formation of solid phases will be preceded by the state of excited atoms corresponding to tetraedric symmetry of electron probability clouds, i.e. the symmetry satisfying the structure of the cubic diamond elementary cell with four equal $\sigma$-bonds. The atoms bonding will be actualized in the direction ensuring maximum enactment of electron wave functions in case of their coupling, and minimal concordance of electron functions, when they are parts of different pairs, because this is the case corresponding to the minimum energy of the system. Consequently, the carbon atom with valent electrons in the state $p$ develops certain lines along which it is most beneficial to form a chemical bond in terms of energy.

Every elementary act of carbon atom joining into a couple or group of atoms in terms of fluctuations or density (concentration) of energy is predetermined by the preliminary consumption of additional energy by atoms or local compressions of atomic carbon in the cloud. Here the time of chemical bond formation is limited by $10^{-3}-10^{-8} \mathrm{~s}$, i.e. the time of excited state duration. The lifetime of atom groups, that entered the chemical bond and have a pre-critical size of the formed complex, is also very short. If the gas density in the carbon cloud is $10^{-17} \mathrm{~kg} /$ $\mathrm{m}^{3}$, there are $\sim 10^{3}$ carbon atoms in $1 \mathrm{~cm}^{3}$; while creation of a stable diamond nucleus takes approximately the same number of atoms. Thus, it is obvious that the history of the stable diamond nucleus formation should be sufficiently long beginning with the occasional act - formation of a bond between two excited carbon atoms and the subsequent break-up of the bond. Emergence of solid particles in the clouds (formation of surfaces) signifies the transfer of the system to a fundamentally new state. With incomplete bonds, the surfaces are characterized by chemically active states, which stimulates the continuation of their growth [80].

In real conditions of interstellar medium, gas clouds cannot be ideally homogeneous. They contain concretions and rarefactions, i.e. small excitations of some or other nature. It is known that any weak concretion in interstellar medium does not disperse but naturally consolidates with time [80]. Atoms collisions also contribute to the enhancement of matter concentration. Hence, the probability of subsequent atoms coalescence increases after each previous act. Eventually, there comes a moment when one of the coalescence acts becomes the last, and there emerges a stable diamond nucleus able to grow. However, this scenario of the assumed mechanism of diamond particle crystallization is the most passive and timeconsuming - it takes about $10^{16}-10^{17} \mathrm{~s}$.

Exponential tempo of reducing time of stable nuclei formation can be stimulated by the shock wave. After the shock wave passage, there will be a short-term rise in gas temperature; but after radiation, the gas quickly resumes its initial temperature and compresses while cooling. The gas density becomes hundreds of times higher [81]. However, this situation is characterized by the fact that the shock wave propagates in the static gas, causing certain excitations. On the other hand, if the carbon gas is the product of explosion in the front of the shock wave propagating from the explosion source (e.g. stars); the transfer from super compressed state from the zone of hot plasma temperatures to the state of density $\sim 10^{-17} \mathrm{~kg} / \mathrm{m}^{3}$, corresponding to the temperatures not more than tens of the absolute scale degrees, will, in some area, actualize as a phase transfer to the diamond. This process is impossible at super high pressure and super high temperature. That is why, similarly to the explosive's detonation, there exists a so-called niche in the on-going process, which is thermodynamically favorable for diamond particles' crystallization. It is probable that these conditions are characterized by definite values of atoms' concentration in a volume unit and energy of their excitation. In works on detonation synthesis, the formation time of diamond nanoparticles from carbon gas will be minimal and, according to $[82,83]$, will be no more than $10^{-7} \mathrm{~s}$. The size of nanosized single crystals is $2^{-15} \mathrm{~nm}$.

Assuming that there is a theoretical possibility of homogeneous diamond crystallization from carbon gas in interstellar medium, it would be logical to prolong the "story" by allowing its participation in the formation of protoplanetary dust-gas cloud. The initial cloud material was the interstellar medium whose composition did not differ dramatically from that of the modern interstellar medium [81]. Protoplanetary cloud had a vortexspiral-shape structure. Such vortex structures are characterized by differential distribution of matter in vortex spirals according to density: lighter components (hydrogen, helium etc.) were mostly concentrated in the center, while heavier ones, like dust particles, were located on the vortex periphery $[84,85]$. Diamond particles, relics of protoplanetary matter, having "settled" in the Earth mantle, passed through the stages of adaptation and conservation. Many of these particles stayed on nanolevel. However, some of them, occurring in favorable physical and chemical conditions, formed diamond deposits on the planet that are different in origin. It should be 
noted that even dramatically deformed solid medium in the regions of vigorous tectonic activity could be favorable for diamond growth.

The authors of $[61,84,85]$ suggested that relic diamond particles could be found in other bodies of the Solar System, e. g. meteorites [86]. This idea was later (1987) proved in the research [1]. Edward Anders and Roy Lewis showed that nanodiamond crystals contain an isotopic mixture of xenon gas, which is absent on Earth, as well as free atomic carbon.

Conclusion. Central inclusions of nano-sized diamond polycrystals are the only preserved Earth-bound witnesses of the first billion of years of life on the planet, and even of the early genesis of the Solar System. From the analysis of experimental results obtained from the physical research into natural diamond crystals and their synthetic analogs, obtained in our experiments, we can conclude that discreteness is a naturally determined process of diamond formation. Discrete diamond growth is determined by thermodynamically metastable conditions in solid, quasi-liquid, gaseous media or in water solution.

Diamond particles can originate spontaneously if there is critical oversaturation of atomic carbon in the system. In space, chemical reactions can take place in a wide range of temperatures - from absolute zero to $1500 \mathrm{~K}$, and practically at any pressure. Carbon atoms become chemically active by absorbing ultraviolet radiation of stars.

It would be premature to state that all diamond monocrystals without exception are analogous to the samples from primary deposits in South Africa and Yakutia, perhaps not correct due to lack of statistical data. It is necessary to study alluvial diamonds, which may have hydrothermal origin and grow on relic polycrystal seeds. It is possible that a part of impact diamond polycrystals can have served as seeds as well.

\section{References.}

1. Lewis, R. S., Ming, T., Wacker, J. F., Anders, E., \& Steel, E. (1987). Interstellar diamonds in meteorites. Nature, 326(6109), 160-162.

2. Minory Ozima, \& Shigeo Zashu (1983). Primitive Helium in Diamond. Science, 219(4588), 1067-1068.

3. Garanin, V. K. (1990). On the issue of the discreteness of natural diamond formation. Mineralogicheskiy zhurnal, (5), 28-36.

4. Petrov, V. S. (1959). Genetic relation of diamonds with kimberlite carbonates. Vestnik MGU. Seriya geologicheskaya, (2), 13-20.

5. Portnov, M. M. (1979). Fluid diapirism as the cause of formation of kimberlite pipes and carbonatite massifs. Doklady AN SSSR, 246(2), 416-420.

6. Nikol'skiy, N. S. (1981). On metastable crystallization of metastable diamonds from the fluid phase. Doklady AN SSSR, 226(4), 954-958.

7. Letnikov, F. A. (1983). Diamond formation in deep tectonic zones. Doklady AN SSSR, 271(2), 433-435.

8. Vasil'yev, Ye. A., Kriulina, G. Yu., \& Garanin, V. K. (2020). Spectroscopic features of the diamond deposit named after M.V. Lomonosov. Zapiski rossiyskogo mineralogicheskogo obshchestva, 149(2), 1-11. https://doi.org/10.31857/s0869605520020082.

9. Rozen, O. M., Zorin, Yu. M., \& Zayachkovskiy, A. A. (1972). Discovery of diamond in connection with eclogites in the Precambrian of the Kokchetav massif. Doklady AN SSSR, 203(3), 674-676.

10. Sidorenko, A.V. (1976). Carboniferous metamorphic complexes of the Precambrian as a potential source of diamond. Doklady $A N$ SSSR, 230(6), 1433-1436.

11. Kaminskiy, F.V. (1976). Alkaline-basalt breccias of the Onega Peninsula. Izestiya AN SSSR. Seriya geologicheskaya, (7), 50-59.

12. Kutyyev, F. SH., \& Kutyyeva, G.V. (1975). Diamonds in Kamchatka basaltoids. Doklady AN SSSR, 221(1), 183-186.

13. Luk'yanova, L. I. (1978). On founds of diamonds in picrites of the Urals. Zapiski Vsesoyuznogo mineralogicheskogo obshchestva, 107(5), 580-585.

14. Abovyan, S. B., \& Kaminskiy, F. V. (1977). On the depth of the of ultramafic rocks formation in the Armenian SSR. Doklady AN ArmS$S R, 65(4), 227-232$.

15. Smirnov, A. A. (1970). Moissonite in Precambrian rocks of Aldan. In Geology and experiment. Research. Moscow: Nedra.

16. Slobodskoy, R. M. (1981). Organoelemental compounds in magmatogenic and ore-forming processes: monograph. Novosibirsk: Nauka.
17. Krishnarao, J.S. R. (1964). Native nickel-iron alloy, its mode of occurrence, distribution and origin. Economic Geology, 59(3), 443448 .

18. Sokhor, M.I., Polkanov, Yu.A., \& Yeromenko, G. K. (1973). Finding of a hexagonal polymorphic modification diamond (lonsdaleite) in placers, Doklady AN SSSR, 209(4), 933-936.

19. Letnikov, F. A., \& Narseyev, V.A. (2016). Kumdykol diamond deposit in northern Kazakhstan. Geologiya i okhrana nedr, 60(3), 7-14. 20. Sobolev, V. V., Taran, Yu. N., \& Gubenko, S. I. (1993). Synthesis of diamond in cast iron. Metal Science and Heat Treatment, 35(1), 3-9. https://doi.org/10.1007/BF00770062.

21. Nikol'skiy, N. S. (1987). Fluid regime of endogenous mineral formation: monograph. Moscow: Nedra.

22. Sobolev, V.S. (1960). Conditions for diamond deposit formation. Geologiya i geofizika, (1), 7-22.

23. Alethea Inns (June 21, 2021). Geological origin of Natural Diamonds. Gemological Science International (GSI). Retrieved from https://gemscience.net/geological-origin-of-natural-diamonds/.

24. Lazko, Ye. Ye. (1979). Heavy diamond concentrates and the genesis of kimberlite rocks: monograph. Moscow: Nedra.

25. Vereshchagin, L. F. (1982). Synthetic Diamonds and Hydroextrusion: a collection of articles. Moscow: Nauka.

26. Kidalov, S. V., Shakhov, F. M., Davidenko, V. M., Yashin, V.A., Bogomazov, I. Ye., \& Vul', A. Ya. (2008). Effect of carbon materials on the graphite-diamond phase transition at high pressures and temperatures. Fizika tverdogo tela, 50(5), 940-944.

27. Prikhna, A. I. (2008). High pressure cleaners in the production of synthetic diamonds (Review). Sverkhtvordyye materialy, (1), 3-22.

28. DeCarly, P. S., \& Jamieson, I. L. (1961). Formation of diamond by explosive shock. Science, 133(3467), 1821-1823. https://doi.org/10.1126/ science.133.3467.1821.

29. Alder, B.J., \& Christian, R.H. (1961). Behavior of strongly shocked carbon. Physical Review Letters, (7), 367.

30. Cannon, P. (1963). Formation of diamond. Journal of the American Chemical Society, 4(22), 4253-4256.

31. Kraus, D., Ravasio, A., Gauthier, M., Gericke, D. O., Vorberger, J., Frydrych, S., ..., \& Roth, M. (2016). Nanosecond formation of diamond and lonsdaleite by shock compression of graphite. Nature, (7), 10970. https://doi.org/10.1038/ncomms10970.

32. Kurdyumov, A. V., Britun, V. F., Yarosh, V.V., Danilenko, A. I., \& Zelyavskii, V. B. (2012). The influence of the shock compression conditions on the graphite transformations into lonsdaleite and diamond. Journal of Superhard Materials, 34, 19-27. https://doi.org/10.3103/ S1063457612010029

33. Chao Wen, Xun Li, De-Yu Sun, Jin-Qing Guan, Xiao-Xin Liu, Ying-Rui Lin, ..., \& Zhi-Hao Jin (2005). Raman spectrum of nanographite synthesized by explosive detonation. Guang Pu Xue Yu Guang Pu Fen $\mathrm{Xi}, 25(1), 54-70$

34. Sozin, YU. I., \& Belyankina, A. V. (1976). Explosion-synthesized diamond substructure. Sinteticheskiye almazy, (5), 27-28.

35. Andreyev, V.D., Lukash, V.A., Voloshin, M. N., \& Vishnevskiy, A. S. (1981). Structure and phase transformations of graphite in cast iron under dynamic loading and morphological characteristics of the resulting diamonds. Fizika i tekhnika vysokikh davleniy, (6), 61-64.

36. Sobolev, V. V., Slobodskoy, V. YA., \& Yegorov, P.A. (1989). Possible mechanism of spontaneous diamond crystallization during shock compression of carbon-containing alloys. In Detonatsiya. Materialy IX Vsesoyuznogo simpoziuma po goreniyu i vzryvu, (pp. 69-72). Suzdal', Chernogolovka. SSSR: OIKHF AN SSSR.

37. Christopher J. Mundy, Alessandro Curioni, Nir Goldman, I-F Will Kuo, Evan J. Reed, Laurence E. Fried, \& Marcella Ianuzzi (2008). Ultrafast transformation of graphite to diamond: an ab initio study of graphite under shock compression. Journal of Chemical Physics, 128(18), 184701. https://doi.org/10.1038/ncomms10970.

38. Turneaure, S.J., Sharma, S. M., Volz, T.J., Winey, M., \& Gupta, Y. M. (2017). Transformation of shock-compressed graphite to hexagonal diamond in nanoseconds, Science Advances, 3(10). https://doi. org/10.1126/sciadv.aao3561.

39. Sobolev, V. V. (January 1987). Diamond crystallization in nature Combustion, Explosion, and Shock Waves, 23(1), 83-86.

40. Sobolev, V. V., Taran, Y. N., \& Gubenko, S. I. (1997). Shock wave use for Diamond Synthesis. Journal de Physique IV, 7(3), C3-73-C375. https://doi.org/10.1051/ip4:1997315.

41. Ferro, S. (2002). Synthesis of diamond. Journal of Materials Chemistry, 1(2,) 2843-2855. https://doi.org/10.1039/B204143J.

42. Taran, Yu. N., Sobolev, V. V., Slobodskoj, V. Ya., \& Gubenko, S. I. (1991). Formation of diamond inclusions in grey iron at combination 
of shock-wave treatment and thermal cycling. Izvestiya AN SSSR: Metally, (3), 140-147.

43. Masaytis, V. L. (1998). Diamond-bearing impactites of the Popigai astrobleme: monograph. Saint Petersburg: VSEGEI.

44. Galimov, E. M. (1973). Cavitation as a mechanism for the diamond origin. Izvestiya AN SSSR. Seriya geologicheskaya, (1), 22-37.

45. Galimov, E. M., Sevast'yanov, V.S., Karpov, G.A., Shilobreyeva, S. N., \& Maksimov, A. P. (2016). Microcrystalline diamonds in the oceanic lithosphere and their possible nature. Doklady RAN, 469(1), 61-64. https://doi.org/10.7868/S0869565216190166.

46. Deryagin, B. D., Fedoseyev, D. V., \& Bakul', V. N. (1971). Physical and chemical sirtez of diamond from gas: monograph. Kiev: Tekhnika. 47. Rudenko, A. P., \& Kulakova, I. I. (1983). On the mechanism and initiation of the growth of diamond crystals under the conditions of chemical mining. In Superhard materials: synthesis, properties, application: reports of an international seminar, (pp. 40-44). Kiev: Naukova dumka.

48. Spitsyn, B. V. (2020). The nucleation of a diamond from an activated gas phase. Fizika tverdogo tela, 62(1), 16-19. Retrieved from https:// www.elibrary.ru/item.asp?id=42571171.

49. Dódnik, S. F., Vasilenko, R. L., \& Voyevodin, V. N. (2014). Preparation and properties of conductive diamond nanocrystalline coatings. Nanosystems, Nanomaterials, Nanotechnologies, 12(2), 213-224.

50. Spitsyn, B. V., \& Alexenko, A. E. (2007). Chemical crystallization of diamond and the diamond coating deposition from gas phase. Protection of Metals, 43(5), 415-431.

51. Barjon, J., Rzepka, E., Jomard, F., Laroche, J.-M., Ballutaud, D., Kociniewski, T., \& Chevallier, J. (2005). Silicon incorporation in CVD diamond layers. Physica Status Solidi, 202(11), 2177-2181. https://doi.org/10.1002/pssa.200561920.

52. Kopf, R.F. (2003). State-of-the-Art Program on Compound Semiconductors XXXIX and Nitride and Wide Bandgap Semiconductors for Sensors, Photonics and Electronics IV: proceedings of the Electrochemical Society. The Electrochemical Society, (2011), 363. 53. Roddy, D. J., Pepin, R. O., \& Mkerrill, R. B. (1977). Impact and explosion cratering. New York: Pergamon Press.

54. Grieve, R.A. F. (1982). The record of impact on Earth: Implications for a major Cretaceous/Tertiary impact event. Geological Society of America Special Papers, (190), 25-37.

55. Sobolev, V. V., Bilan, N. V., \& Khalimendik, A. V. (2017). On formation of electrically conductive phases under electrothermal activation of ferruginous carbonate. Naukovyi Visnyk Natsionalnoho Hirnychoho Universytetu, (4), 27-35.

56. Pivnyak, G. G., Sobolev, V. V., \& Filippov, A. O. (2012). Phase transformations in bituminous coals under the influence of weak electric and magnetic fields. Naukovyi Visnyk Natsionalnoho Hirnychoho Universytetu, (5), 43-49.

57. Soboliev, V., Bilan, N., \& Samovik D. (2013). Magnetic stimulation of transformations in coal. Mining of Mineral Deposits, 221-225. https://doi.org/10.1201/b16354-2.

58. Kravchenko, V. M., \& Sobolev, V. V. (2002). Conditions and processes of ore-forming contraction strain of ferruginous quartzites in zones of dislocation metamorphism. Dopovidi NAN Ukrayiny, (4), 129-132.

59. Mindeli, E. O., Chagelishvili, E.SH., \& Mechurchlishvili, T. I. (1980). Electron diffraction studies of diamonds synthesized under extreme conditions. Fizika i tekhnika vysokikh davleniy, (2), 56-58. 60. Sobolev, V. V., Didyk, R. P., Slobodskoi, V. Ya., Merezhko, Yu. I., \& Skidanenko, A. I. (1993). Dynamic effects in the production of diamond from solid-solution carbon. Combustion, Explosion, and Shock Waves, 19(5), 658-659. https://doi.org/10.1007/BF00750451.

61. Sobolev, V. V., Gubenko, S. I., Rudakov, D. V., Kyrychenko, O. L., \& Balakin, O. O. (2020). Influence of mechanical and thermal treatments on microstructural transformations in cast irons and properties of synthesized diamond crystals. Naukovyi Visnyk Natsionalnoho Hirnychoho Universytetu, (4), 53-62. https://doi.org/10.33271/nvngu/2020-4/053. 62. Sobolev, V.V., Taran, Yu. N., \& Gubenko, S. I. (1993). Synthesis of diamond in cast iron. Metallovedenie i Termicheskaya Obrabotka Metallov, (1), 2-6.

63 Sobolev, V. V., \& Bondarenko, E. V. (1993). The change in granulometric composition of diamond crystals when treating synthesis products in electromagnetic field. Sverkhtverdye Materialy, (4), 57-58. 64. Sobolev, V.V. (1994). The Diamond Synthesis: Experimental Studies of Hard-Phase Epitaxy. Sverkhtverdye Materialy, (4), 340-347. 65. Trofimov, V.S. (1980). Geology of natural diamond deposits: monograph. Moscow: Nedra.

66. Garanin, V.K., \& Kudryavtseva, G.P. (2006). Polygenicity and discreteness of natural diamond formation. Moscow: Akademik V. I. Smirnov Fund. Smirnovskiy sbornik.
67. Gurney, J.J., Helmstaedt, H.H., Le Roex, A.P., Nowicki, T.E., Richardson, S. H., \& Westerlund, K. J. (2005). Diamonds: Crustal Distribution and Formation Processes in Time and Space and an Integrated Deposit Model. Economic Geology, 100 ${ }^{\text {th }}$ Anniversary Volume, 143-177. 68. Bartoshinskiy, Z. V., \& Kvasnitsa, V. N. (1991). Crystallomorphology of kimberlite diamond: monograph. Kiev: Naukova dumka.

69. Bulanova, G. P., Barashkov, Yu. P., Tal'nikova, S. B., \& Smelova, G. B. (1993). Natural diamond - genetic aspects: monograph. Novosibirsk: Nauka.

70. Dishler, B. (2012). Handbook of spectral lines in diamond. Springer. 71. Bokiy, G. B., Bezrukov, G. N., Klyuyev, YU.A., Nalotov, A. M., \& Nepsha, V. I. (1986). Natural and synthetic diamonds: monograph. Moscow: Nauka.

72. Khachatryan, G.K., Palazhchenko, O.V., \& Garanin, V.K. (2008). Genesis of "nonequilibrium" diamond crystals from the Karpinsky-1 according to cathodic luminescence and IR spectroscopy data. Vestnik Moskovskogo Gosudarstvennogo Universiteta, (2), 38-45. 73. Chernai, A.V., Sobolev, V.V., Chernaj, V.A., Ilyushin, M.A., \& Dlugashek, A. (2003). Laser initiation of charges on the basis of di-(3hydrazino-4-amino-1,2,3-triazol)-copper (II) perchlorate. Fizika Goreniya i Vzryva, 39(3), 105-110. https://doi.org/10.1023/A:1023852505414. 74. Danilenko, V. V. (2010). Explosion: physics, engineering, technology: monograph. Moscow: Energoatomizdat.

75. Garanin, V. K., Digonskiy, S. V., \& Kudryavtseva, G. P. (2006). Model of natural diamond formation in the aspect of its synthesis. Article 2. Genesis of diamond in meteorites, metamorphic rocks and kimberlites. Izvestiya VUZov. Geologiya i razvedka, (2), 8-14.

76. Galimov, E. M. (1984). 13C/12C of diamond. Vertical zoning of diamond formation in the lithosphere. In Geochemistry and Cosmochemistry. Materials of the $27^{\text {th }}$ International Geological Congress, (110123). Moscow: Nauka.

77. Breusov, O. N., Volkov, V.M., Drobyshev, V.N., \& Tatsiy, V.F. (1984). Experimental and theoretical study of the oxidation of diamond micropowders by the DTA method. In Interaction of diamonds with liquid and gaseous media, (19-35). Kiev: ISM AN USSR.

78. Breusov, O. N., Tatsiy, V. F., \& Shunina, I. G. (1989). Evaluation of the oxidation resistance of diamond micropowders by the temperature of the maximum DTA curves. Sinteticheskiye almazy, (1), 25-28.

79. Konovalenko, A. A. (1984). Observations of carbon recombination lines at decameter waves in the direction of the Cassiopeia A source. Pis'ma v Astronomicheskiy zhurnal, 10(11), 846-853.

80. Sobolev, V.V., Bilan, N. V., Baskevich, A. S., \& Stefanovich, L. I. (2018). Electrical charges as catalysts of chemical reactions on a solid surface. Naukovyi Visnyk Natsionalnoho Hirnychoho Universytetu, (4), 50-58. https://doi.org/10.29202/nvngu/2018-4/7.

81. Tsitsin, F.A. (2009). Essays on the modern cosmogony of the solar system: monograph. Dubna: Feniks.

82. Danilenko, V. V. (2013). Synthesis and sintering of diamond by explosion: monograph. Moscow: Energoatomizdat.

83. Yamaguchi, S. (1983). Obtaining diamond and boron nitride by the internal explosion method. In Superhard materials: synthesis, properties, application, (55-57). Kiev: Naukova dumka.

84. Sobolev, V. V., \& Bilan, N. V. (2018). Physical conditions of the 'light' core formation and thermonuclear heat source deep inside the earth. Naukovyi Visnyk Natsionalnoho Hirnychoho Universytetu, (5), 13-23. https://doi.org/10.29202/nvngu/2018-5/1.

85. Sobolev, V., \& Hove Hogset, I. (1997). Phenomenon of spiral vortex formation over the shock wave front. Journal De Physique. IV: 7(3), 127-129.

86. Sobolev, V. V. (1985). The hypothesis of the formation of diamond in nature and the possible reasons for its widespread distribution on Earth. In Detonation. Tez. dokl. III Vses. soveshch. po detonatsii, (p. 174). Tallinn-Chernogolovka: OIKHF AN SSSR.

\section{Метастабільне алмазоутворення при складних фізико-механічних впливах}

\section{В. В. Соболєв ${ }^{1}$, О. С. Ковров ${ }^{1}$, М. М. Налисько ${ }^{2}$, Н. В. Білан ${ }^{1}$, О. А. Терешкова ${ }^{1}$}

1 - Національний технічний університете «Дніпровська політехніка», м. Дніпро, Україна, e-mail: velo1947@ukr.net 2 - Державний вищий навчальний заклад «Придніпровська державна академія будівництва та архітектури», м. Дніпро, Україна 
Мета. Синтезувати полікристали алмазу в термодинамічно стабільній області, а нарощування монокристальної оболонки провести в умовах термодинамічної метастабільності. Дослідити деякі фізичні властивості та особливості внутрішньої будови синтезованих монокристалів для розробки нових моделей і гіпотез у проблемі генезису алмаза.

Методика. Експериментальні дослідження із застосуванням ударно-хвильових впливів на металевий сплав, що містить не алмазний вуглець. Використані методи інфрачервоної, ультрафіолетової спектроскопії, рентгенофазового аналізу, електронний парамагнітний резонанс, ізотопний аналіз, диференційний термічний аналіз, електронну мікроскопію та ін. Синтез нанокристалічних алмазних частинок, як зародків для вирощування монокристалів, здійснюється ударно-хвильовим методом з використанням профільованих ударних хвиль.

Результати. Проведено комплекс фізико-хімічних досліджень вирощених монокристалів алмазу; встановлені та проаналізовані причини, що викликають дискретне зростання алмазу та збереження у процесі росту центрального включення - полікристалічного алмаза ударно-хвильового походження. Показано, що дискретність алмазоутворення характерна тільки для термодинамічно метастабільних умов. Результати експериментів дають підставу припустити метастабільне зростання, у тому числі, і алмазів корінних родовищ.

Наукова новизна. Отримала розвиток гіпотеза про походження алмазних наночастинок у міжзоряних вуглецевих хмарах, що відносяться виключно до центральних полікристалічних включень у монокристальній оболонці алмазів. Гіпотеза усуває наукове протиріччя, що виникає у всіх випадках спроби інтерпретувати природну дискретність алмазоутворення на підставі закономірностей діаграми стану «графіт-алмаз». Розглянуті можливі причини дискретного алмазоутворення у природі та сценарій утворення нанокристалів алмаза в міжзоряній хмарі атомарного вуглецю.

Практична значимість. Значимість результатів експериментальних досліджень полягає в розробці не енергоємної технології вирощування великих монокристалів алмазу в умовах температур 500-1400 K і тисків $10^{5}-10^{7}$ Па.

Ключові слова: алмаз, метастабільність, дискретність, алмазоутворення, центральний зародок, протопланетна хмара

Recommended for publication by M.V.Ruzina, Doctor of Geological Sciences. The manuscript was submitted 10.12.20. 